\title{
Customer Satisfaction: A Comparison of Public and Private Banks Of Pakistan
}

\author{
${ }^{1}$ Waqar ul Haq ${ }^{2}$ Bakhtiar Muhammad \\ ${ }^{I}$ ShaheedZulfikar Ali Bhutto Institute of Science and Technology, Islamabad \\ ${ }^{2}$ Professor, Shaheed Zulfikar Ali Bhutto Institute of Science and Technology, Islamabad
}

\begin{abstract}
The purpose of conducting this research is to compare public and private sector banks of Pakistan by evaluating their customer satisfaction. This research is mainly based on primary data which has been collected through a well-structured questionnaire (adapted from three different studies). The questionnaire has been distributed to 351 different respondents on different chosen locations. This paper makes a useful contribution as there are very low number of studies has been conducted in Pakistan on such areas like price, technology, reliability, customer service, location and infrastructure. This research shows that customer satisfaction varies from person to person and, bank managers need to conduct more researches in order to evaluate customer satisfaction more strongly.
\end{abstract}

Keywords: Customer satisfaction, customer services, technology, reliability

\section{Introduction}

1.1 Customer Satisfaction: is a measure of how products and services provide by any organization meet the expectations of a customer. It varies from person to person and service to service. A customer can be defined as a user or potential user of banking services. A customer would include an account holder, or a person carrying out casual business transactions with a bank. The efficiency of a banking sector depends upon how best it can deliver services to its target customers. In order to survive in this competitive environment and provide continual customer satisfaction, the banking services providers are required to frequently increase the quality of services. In banking business it is seen that only 5\% increase in customer retention can extend $35 \%$ profitability.

\subsection{Entrance of Technology}

\section{Literature Review}

Private sector Banks seem to have satisfied its customers with good services and they have been successful in retaining their customers by providing better facilities than Public sector Banks. But, still Private Banks need to go a long way to become customer's first preference. In an economy of innovative technologies and changing markets, each and every service quality variable has become important. New financial products and services have to be continuously introduced in order to stay competent and Private Banks need to concentrate more on their credit facilities and insurance services since customers do not have a very good opinion about these facilities being offered by Private Banks also Public sector banks enjoy the trust of the customers, which they have been leveraging to stay in the race however they need to improve their service quality by improving their physical facility, infrastructure and giving proper soft skill trainings to their employees(Puja et, al).

In the banking sector it is necessary to increased adoption of technology to better meet customer requirements, improve efficiencies, reduce costs and ensure customer delight and it was the private sector and foreign banks which established the technological revolution in Indian banking and considering the fact that in the new economy, mind share leads to market share and mind share is influenced not only by the promotions and advertisements but more importantly on favorable customer perception which in turn is based on satisfaction with regard to products, services and interaction (B. K. Tiwary).

The private sector banks are providing more satisfied ATM services then public sector banks and the customer perception about Productivity, Security and Sensitivity, Cost Efficiency, Problem Handling, Compensation and Contact services related to ATM service is very less in both the public sector and privates sector banks, Therefore both kinds of banks should be aware about these facets of ATM service to improve customers' satisfaction (Vijay M. Kumbhar).

The entry of information technology into the banking industry has created a revolution and it has prompted commercial banks of India to design world-class customer service systems and practices, to meet the growing customer needs. It is interesting to note that the results are consistent with the previous studies conducted on customer service aspects, and it has been observed that the foreign and the new generation private sector banks are serving the customers better (Rengasamy et, al). 


\subsection{Customers Perceptions and Expectations}

Quality expectation and the valuation of services received are slightlymore in the private sector banks as compared with the public sector banks. The effects for tactic since sectorial differentiation become veryblurry as a result of increasing correspondence between services and struggle from linked and additional industries (Peter et, al).

Service quality is one of main elements of customer satisfaction and their intention to purchase. However, the customers of public and private sector banks different in terms of their perception of service quality. Private Banks have been observed to be higher on dimensions of service quality: effectiveness and convenient while, the nationalized banks are better on the dimensions of price and consistency (Sachinet, al).

Private bank customers are more satisfied with the services then public banks. Managers in the banking sector undertake significant efforts to conduct customer satisfaction surveys and it is appears that customers are saying that they expect good products and quality to their banks and that may the only thing important to them (Muhammad Naveed).

\subsection{Image and Reputation of Banks}

Some publicly owned banks are scoring well among customers but overall analysis shows that satisfaction rate in customers of private banks is much higher than public sector banks and people will continue the mortgage with private banks then public because they're impressed by the level of honesty of private banks (Colin Beasty).

\subsection{Performance of Banks}

After the privatizations of state-owned banks, their performances in comparison with other banking groups have increased by $95 \%$. The performance of private banks after privatization of state banks had significant reduces and this reduction indicates that the share of the market of newly privatized state-owned banks increased. Although the performance of privatized state banks after privatization has increased significantly (Khodaei et, al).

The economic reforms and the entry of private players have cause nationalized banks to revamp their services and product portfolios to incorporate new, innovative customer-centric schemes. Nowadays, due to the rise in competition, customer satisfaction is considered to be the most important thing in retail services but there is no noteworthy difference in customer satisfaction of public sector and the private sector banks (Vigget, al).

\subsection{Price and Packages}

Cheque deposits and cheque clearing are most common services used by customers, the charges levied by the bank on these services are higher in private and foreign banks then in nationalized banks. Their study also shows that the customers of public banks were not much satisfied with the behavior of employee and infrastructure, while customers of private and foreign banks were not much satisfied with high charges, approachability and communication. They have also suggested that training on stress management and public dealing should be imparted to the employees of nationalized banks and nationalized banks need to improve their infrastructure and ambience to compete with private and foreign banks in India (Surabhiet, al).

Credit cards have become a part of life. In recent years there was a lot of demand has been shown for credit cards and there is a lot of scope for credit cards business in India. The credit cardholders consider eleven 'very important' variables which "Satisfied" them are: Joining Fee, Annual fee, Minimum payment due, Cash withdrawal possibility, Availability of ATMs, Life Insurance Cover, Card replacement fee, Air insurance, Baggage cover, lost card liability-after losing the card and lost card liability-before losing the card (Chennappa, D; Eliat, M.J).

\subsection{Location and Infrastructure}

Good sites and suitable site of the branch are essential for bank branches for smooth operation of banking business. When the private banks were compared with public banks, all the private banks have excellent locations from business point of view compared to public banks in India and for providing better service to customers proper training should be given to the staff by the banks also public sector banks should invest and concentrate more on staff development where as private sector gives more priority on infrastructural aspects. The rigid policy of public banks creates more dissatisfaction among the customers while for private banks mostly the value of service is the key factor of satisfaction (Uma et, al).

\subsection{Quality of Customer Services}

First dimension of customer satisfaction for nationalized banks is Service Orientation but, for private banks Service orientation appeared as second dimension and they focuses more on customer satisfaction and nationalized banks give more importance to Flexibility in Use of Services, Vision and Competency. Also customers of nationalized banks had not been given much importance by the executives. On the other hand 
customers of private banks had been offered these services right from the beginning therefore, customers of private banks more satisfied (Jitendra Kumar Mishra).

The consumers of nationalized banks are more satisfied with service quality, than private banks and it's required to ascertain the key success aspects in the industry, in terms of satisfaction of customers by keeping in view the growing market size and the strong competition (Pooja Mengi).

The Private Banks came to existence within the last ten years with the objective of to limit the government intervention in banks and from since then they try hard to obtain customer satisfaction even after a short period of existence. According to a survey the result shows that private sector banks are more popular to obtain customer satisfaction than the public sector banks (Farzad Asgarian).

Satisfaction of customers is the most important forecaster of service quality of banking sector. Management of banks should confirm that the banking atmosphere should focus on quick and fair services to their customers. Public sector banks are contributing more credit facility to fishermen and farmers than private banks and the State Government announcement of giving the agricultural loan has given more satisfaction to the consumers of public banks (N. Senthi kumar et, al).

The effort towards ease of banking and accessibility is preferred by the customer who is more seen in private banks then public and customer care and customer retention programs should take into consideration by public banks. In Kuwait Muslim customers are satisfied more with accessibility of ATM machines in multiple locations, funds safety, ease to use ATM machines and service quality provided, but the worse element which has been noticed in this study was that the interest rate on loans, which was the indicator of that the most of customer in Kuwait give more intention to loans (Khaled et, al).

Service quality is an important feature of customer satisfaction in Indian banking industry irrespective of public sector and the private sector banks and Customer satisfaction is found to be strongly associated with propensity to recommend (Monica Bedi)

Some of the respondents choose the SBI bank is because the bank is proving more ATM facility to the customers and many of the respondents are saying the reason to choose the services of the SBI bank is because they are good in efficient customer service but many of the respondents are not aware of the many services Provided by the SBI bank. The few are deposit of cash in ATM, request for cheque book in ATM, end of the day balance in mobile, etc. While some of the respondents choose the ICICI bank is because the bank is more reliable to the customers and many of the respondents are saying the reason to choose the services of the ICICI bank is because they are good in efficient customer service and efficient complaint handling. So finally both the banks are competing equally with each other but SBI bank is little bit below the line in customer complaints handling when compared to ICICI bank (M.J. Vidhyaa).

\section{Research Framework}

A research framework has been developed to compare customer satisfaction among private and public sector banks of Pakistan which includes research methodology, research model and questionnaire.

\subsection{Methodology}

A method has been designed to meet the objectives of research. For this purpose a questionnaire has been adapted from three different research studies [1.Salman Khalid et al (2011), 2.Uma Shankar et, al (2010) and 3.Khaled Al-Hashash et, al (2008)] and circulated in 5 different cities of Pakistan (Sukkur, Lahore, Islamabad, Rawalpindi and Peshawar). This questionnaire consists of two different parts. The first part is showing respondents personal data such as gender, bank type, income, age, qualification and the second part asked respondent to rate their satisfaction level to their bank from "strongly agree" to "strongly disagree" on such variables which lead to build strong relationship with customers such as prices, reliability, technology, customer service, location and infrastructure etc. This questionnaire was given to 500 different respondents out of which 351 questionnaires were returned. Most of these responses were conducted myself and rest through the help of friends and family. 


\subsection{Research Model}

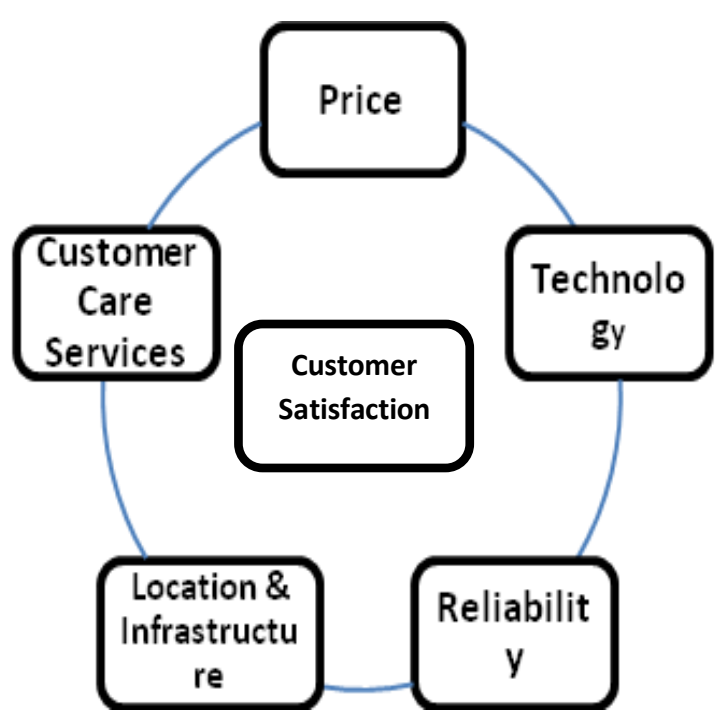

\section{FINDINGS}

\subsection{Background of Respondents}

The first part of this questionnaire was designed to collect personal information of respondents such as their gender, Age, bank type, income and qualification and the investigation shows that $65 \%$ of the respondents are male and $35 \%$ are female of which, $42 \%$ of the respondents are having their account in public banks and $58 \%$ have their account in private banks. $72.6 \%$ respondents are from age group $18-25$ years, $16.9 \%$ are from age group $26-33$ years, $5.7 \%$ are from age group $34-41$ years, $1.7 \%$ is from age group $42-50$ years and $3.1 \%$ are from age group $51+$ years. In terms of qualification only $0.6 \%$ are under matric, $1.6 \%$ have done matric, $4.4 \%$ respondents have done intermediate, $76.2 \%$ are graduated and $17 \%$ respondents are post graduated. In income segment $26 \%$ of the respondents having less than 20 thousand, $11.8 \%$ have $21-30$ thousand, $18.5 \%$ earn $31-50$ thousand, $33.5 \%$ earn $51-100 \mathrm{~K}$ and only $10.2 \%$ of the respondents earn more than 100 thousand per month.

\subsection{Mean Std. Deviation of Each Question}

\begin{tabular}{|l|c|c|c|c|c|}
\hline \multicolumn{1}{|c|}{ Questions } & N & Minimum & Maximum & Mean & $\begin{array}{c}\text { Std. } \\
\text { Deviation }\end{array}$ \\
\hline My bank gives me good compensation. & 349 & 1.00 & 5.00 & 1.8195 & 1.10592 \\
\hline Services charges my bank imposes is competitive. & 350 & 1.00 & 5.00 & 2.0514 & .93188 \\
\hline My bank gives good interest rate on saving accounts. & 349 & 1.00 & 5.00 & 2.1519 & 1.06262 \\
\hline My bank provides variety of service charges. & 350 & 1.00 & 5.00 & 2.2000 & 1.07325 \\
\hline My bank provides good credit facilities. & 346 & 1.00 & 5.00 & 2.2659 & 1.19120 \\
\hline $\begin{array}{l}\text { My bank doesn't charge unnecessarily for not } \\
\text { maintaining minimum balance in account. }\end{array}$ & 346 & 1.00 & 5.00 & 2.3642 & 1.19917 \\
\hline My bank provides ATM service in multiple locations. & 350 & 1.00 & 5.00 & 1.8971 & 1.05480 \\
\hline My bank provides good E-Banking service. & 348 & 1.00 & 5.00 & 2.1810 & 1.05415 \\
\hline My bank provides Phone account service facilities. & 346 & 1.00 & 5.00 & 2.1821 & 1.12357 \\
\hline My bank provides Internet banking service. & 351 & 1.00 & 5.00 & 2.1368 & 1.14072 \\
\hline My bank provides safety for my funds. & 349 & 1.00 & 5.00 & 1.9484 & 1.00440 \\
\hline My bank's image and reputation is good. & 344 & 1.00 & 5.00 & 2.1686 & 1.11473 \\
\hline $\begin{array}{l}\text { I have open account in this bank because for personal } \\
\text { relationship with any of the employee. }\end{array}$ & 350 & 1.00 & 5.00 & 2.2486 & 1.25921 \\
\hline Location of my bank is convenient. & 348 & 1.00 & 5.00 & 2.0460 & 1.14543 \\
\hline
\end{tabular}


Customer Satisfaction: A Comparison of Public and Private Banks of Pakistan

\begin{tabular}{|l|c|c|c|c|c|}
\hline \hline My bank has multiple branches in Pakistan. & 347 & 1.00 & 5.00 & 2.0259 & 1.09751 \\
\hline My bank provides good parking space facility. & 347 & 1.00 & 5.00 & 2.1326 & 1.19718 \\
\hline Infrastructure of my bank is attractive and friendliness. & 351 & 1.00 & 5.00 & 2.2393 & 1.19511 \\
\hline My bank staff attitude is friendliness. & 350 & 1.00 & 5.00 & 2.0543 & 1.07587 \\
\hline My bank staff gives prompt attention to my needs. & 345 & 1.00 & 5.00 & 2.0812 & .98496 \\
\hline My bank staff understands my needs. & 347 & 1.00 & 5.00 & 2.1729 & 1.06660 \\
\hline My bank staff handles my problems efficiently. & 350 & 1.00 & 5.00 & 2.2000 & 1.13552 \\
\hline My bank provides me a good customer service. & 347 & 1.00 & 5.00 & 2.1441 & 1.09491 \\
\hline My overall opinion about my bank is good. & 348 & 1.00 & 5.00 & 2.1810 & 1.12810 \\
\hline I am satisfied with my bank. & 345 & 1.00 & 5.00 & 2.1710 & 1.08493 \\
\hline I will not switch to any other bank. & 348 & 1.00 & 5.00 & 2.3247 & 1.14170 \\
\hline
\end{tabular}

\section{Conclusion}

Above analysis shows that customer satisfaction vary according to the nature of the services and in this case, highest customer satisfaction is shown in such areas like price charged by banks is nominal, convenient location of bank branches and staff attitude toward problem solving of customers. When the private sector banks are compared with public sector banks, private bank customers were more satisfied with their bank because of their multiple branches at convenient locations and technology (like check deposit machines, utility bill accepting machines etc.) which were not even seen in public sector banks. But when we talk about public sector banks customers of public sector banks were more satisfied with reputation, reliability and the prices which public sector banks impose on services like cheque/cash deposit and cheque/cash withdraw (it has been shown that price charges are lower in public sector banks than in private sector). When we compare both types of banks in terms of customer care service, private sector banks are favored more than public sector banks. Although overall both public and private sector bank customers are satisfied with their banks but due to wide difference of response, both public and private sector banks should concentrate on their weak areas in order to meet their customer expectations and this study provides sort of guidelines to managers of banks to take suitable decisions to get more satisfied responses from their customers.

\section{Limitations of the Study}

Four limitations have been observed during this research. First, the research only focuses on public and private banks, other banks like Foreign and Micro financial institutions that also plays good role in Pakistani banking industry, has not been included in this research. Second, a limited number of cities were covered in this research (Sukkur, Lahore, Islamabad, Rawalpindi and Peshawar only). Third, the sample size and actual respondent numbers were limited because of limited time period. Finally, permission to carry out study inside and outside banks has not been given so I had to reach respondents individually which has consumed a lot of time as well.

\section{References}

[1]. B. K. Tiwary (2011). Consumer Perception and Satisfaction of Banking Products and Services - A Comparative Study of Select Indian Public and Private Sector Banks. Indian Streams Research Journal Vol - I. Chennappa, D; Eliat, M.J (2009). Satisfaction of the Credit Card Holders of the Public, Private and Foreign Sector Banks. European Journal of Management Volume: 9 , ISSN: 15554015.

[2]. Colin Beasty (2005). Private Banks Rate High in Customer Satisfaction. CRM Magazine (Article\# 43360).

[3]. Farzad Asgarian(2009). A Comparative Study on Service Quality and Customer Satisfaction of Public Banks and Private Banks in Iran. Las Vegas International Academic Conference. Jitendra Kumar Mishra (2007). Constitute Dimensions of Customer Satisfaction: A Study of Nationalized and Private Banks. Revista Tinerilor Economisti (The Young Economist Journal)vol. 1, issue 8 , pages 40-47.

[4]. Khaled Al-Hashash and Abdulrasoul HussainBahzadi (2008). Bank's Customer Satisfaction In Kuwait: An Exploratory Study. Open University Malaysia.

[5]. Mohammad Khodaei Valahzaghard, Parinaz Koozehgar, Hassan Khodaei Valehzagharad \& Mostafa Memarzade (2012).The Comparison of Private State Banks and Other Banks in Iran.European Journal of Social Sciences ISSN 1450-2267 Vol.27 No.4.

[6]. Monica Bedi (2010). An Integrated Framework for Service Quality, Customer Satisfaction and Behavioral responses In Indian Banking Industry a Comparison of Public and Private Sector Banks. Journal of Services Research Volume: 10, Issue: 1, Pages: 157172 .

[7]. Muhammad Naveed (2009). Customer Satisfaction in Banking Sector. National University of Modern Languages. 
Customer Satisfaction: A Comparison of Public and Private Banks of Pakistan

[8]. M.J. Vidhyaa (2009). A Comparative study of customer services in ICICI (Industrial Credit And Investment Corporation Of India) and SBI (State Bank of India). ICFAI National College, KEELKATTALAI.

[9]. N. Senthikumar, A. Ananth and A. Arulraj (2011). Impact of Corporate Social Responsibility on Customer Satisfaction in Banking Service. African Journal of Business ManagementVol.5 (7), pp. 3028-3039.

[10]. Peter Kangis \& Vassilis Voukelatos (1997). Private and Public Banks: A Comparison of Customer Expectations and Perceptions. International Journal of Bank Marketing, Vol. 15 ISSN: 7, pp.279 - 287.

[11]. Puja Khatri \& Yukti Ahuja (2010).Comparative Study of Customer Satisfaction in

Indian Public Sector and Private Sector Banks. International Journal of Engineering and Management Sciences Vol. 1: 42-51.

[12]. Pooja Mengi (2009). Customer Satisfaction with Service Quality: An Empirical Study of Public and Private Sector Banks. The IUP Journal of Management Research, Vol. VIII, No. 9, pp. 7-17.Rengasamy Elango and Vijaya Kumar Gudep (2006). A Comparative Study on the Service Quality and Customer Satisfaction among Private, Public and Foreign Banks. The IUP Journal of Marketing ManagementIJMM10608.

[13]. Surabhi Singh \&Renu Arora (2011). A Comparative Study of Banking Services and Customer Satisfaction in Public, Private and Foreign Banks. Kamla- Raj, J Economics J Economics, 2(1): 45-56.

[14]. Uma Sankar Mishra, Bibhuti Bhusan Mishra, Swagat Praharaj \& Ramchandra Mahapatra (2011). CRM in Banks: A Comparative Study of Public and Private Sectors in India. European Journal of Social Sciences Volume 24.

[15]. Dr. Vijay M. Kumbhar (2011). Service Quality Perception and Customers Satisfaction in Internet Banking Service: A Case Study of Public and Private Sector Banks. Cyber Literature Volume 4 Issue 2 ISSN 0972-0901. 